\title{
DECISION-MAKING MECHANISMS REGARDING THE ESTABLISHMENT OF THE FINANCING SOURCES OF THE INVESTMENT PROGRAMS IN PUBLIC UTILITY SERVICES
}

\author{
Aniko KUNTZ, Cristina DRIHA \\ Doctoral School of Economic Sciences, Faculty of Economic Sciences, University \\ of Oradea, Oradea, Romania \\ ancsaktz@gmail.com \\ cristina.driha@gmail.com
}

\begin{abstract}
This paper is an empirical study that addresses a topical issue in terms of decision-making methods for setting up sources of funding for investment programs in public utilities in Romania. In order to ensure a high level of security and accessibility, equal treatment, promotion of universal access and users' rights, public utilities are subject to specific public service obligations. Considering that in the utilities services there is still a process of implementation of the European requirements regarding the satisfaction of the quantitative and qualitative requirements of the users; consumer protection and quality of life, environmental conservation in accordance with specific regulations in force, sustainable development, protection and capitalization of the public and private domain of territorial administrative units, it is necessary to introduce modern management methods to achieve these desired. The deepening of the notions, of the particularities in the field, creates the premises for finding optimal and viable solutions regarding the improvement of the legal framework of functioning and operation in the public utilities services, so that the decisional and financial mechanisms are the optimal ones in the concrete socio-economic conditions. Considering the public and permanent functioning of the public utility services, the approached topic is of a real interest for any entity in the field concerned with the efficient, economic and effective management of the public utility system. In this regard, the establishment of the maintenance, replacement, development fund for all entities in the field of public utility services (and not only for those receiving external funds) is a real opportunity, highlighted and supported by existing investment programs in the field of water, sewerage, wastewater treatment and rainwater collection.
\end{abstract}

Keywords: public utility services, public utility system, royalty, development replacement maintenance fund, public utility service

JEL Classification: K11, L32, L95, L97, L98.

\section{Introduction}

Public utility services with an impact on housing are those public services that through the organization and functioning must ensure, as also provided by national legislation, a higher level of quality and safety, promoting the principle of universality, accessibility and equal treatment for all users, ensuring transparency regarding their rights. The sum of the services that ensure the satisfaction of the basic public and social requirements of the communities represents the public 
utility services. These include: "the following areas: water supply; sewerage and wastewater treatment, collection, sewerage and drainage of rainwater; thermal energy supply in centralized system; sanitation of localities; public lighting; natural gas supply; local public passenger transport" due to the Law no. 225/2016 amending and supplementing the Law on community services of public utilities no. $51 / 2006$, updated. These services are provided by the technical-municipal infrastructure specific to each field of activity, being included in the public domain of the locality in which it is located. They are called public utility systems by the legislator.

We notice the fundamental difference between the notion of: public utility service which represents the set of activities of general interest carried out for the inhabitants of a community operating with the goods from the public utility system and the second notion, which represents a set of goods.

In order to follow the evolution at terminological and conceptual level, through the prism of the legal and constitutional framework, but also from the perspective of transposing the European directives in the national legislation that marked each period after the 90 s we studied authors such as: Anastase, I., (2008), Bancioi and Zaharia (2006), Bedrule-Grigoruta, M., V., (2007), Bucurean, M., (2006), Constantin, DL, (2004), Corcodel, Şt.F., (2016), Demeter and Klarik (2003), Dinu (2016), Dumitraşcu, V., (2006), Grigorescu (2010), Focşăneanu (2011), Horvath (2001), Icu (2020), Klarik (2004), Kolumban (2003), Matei and Anghelescu (2010), Miricescu and others (2010), Puie, O., (2012). Niculescu, M., Lavalette, G. (1999), Parlagi, A., P., (2009) and last but not least the national legislation.

\section{The architecture of the system of organization and functioning of public utility services in Romania}

The architecture of the system of organization and functioning of public utility services reflected the form of implementation of the central and local public administration reform over the years, undergoing a series of changes imposed by the existing situation at national level, as well as by the objectives and strategies assumed by the Treaty. Romania's accession to the European Union in terms of environmental and quality requirements.

Beginning with 90's, the entities operating in the public utility services have undergone a series of changes, as follows: the county enterprises of communal households are transformed into enterprises of local subordination, only to later become autonomous companies, distinct or not, by types of activity. However, the way of organization, the pace of change was strongly influenced by the type of public utility, by special regulations in each field (eg: the field of electricity has a different evolution from local transport), so that the architecture of the system of organization and operation of public utility services is different from an administrative point of view (local, county) even within the same type of activity (an eloquent example is the field of drinking water and sewerage services). Autonomous utilities are publicly owned economic units, which have taken over in their patrimony the entire assets of state enterprises, without making the difference between the public and private patrimony of the state, respectively between the public and own patrimony of the utility. With the accession to the European Union, the need arose for the legal regulation of competences in the different types of public utility services, thus, the exercise of exclusive competences by the local 
public administration authorities at the level of communes and cities was provided regarding the supply of water, sewerage and sewage treatment, public lighting, sanitation and local public passenger transport (art. 21, letter f) -i) of the Framework Law on decentralization no. 195/2006, with subsequent amendments and completions) and the exercise of powers shared by the local public administration authorities at the level of communes and cities with the central public administration authorities regarding the supply of thermal energy produced in a centralized system (art. 24, letter a) of Law no. 195/2006, with subsequent amendments and completions).

At the same time, "responsibilities for the provision of some of the Community services of public utility may fall to inter-community development associations, which are cooperation structures acting on the basis of the mandate granted by decisions of the deliberative authorities of the member administrative-territorial units and the statute of the association" (Law on local public administration no. $215 / 2001$, with subsequent amendments and completions). The purpose of the inter-community development association is to establish, organize, regulate, finance, operate, monitor and jointly manage the public utility services provided within the competence of the member administrative-territorial units, as well as the joint realization of projects and public investments of zonal or regional interest destined to the establishment, modernization and / or development, as the case may be, of the systems of public utilities afferent to these services, as a structure of collaboration and inter-community cooperation of the member administrativeterritorial units.

In February 2006, the Romanian Government approved the national strategy on accelerating the development of community public utility services, a national strategy that was the basis for the substantiation, elaboration and implementation of the Multiannual Plan for the development of community public utility services (art. 1 of Decision no. 246 of 16 February 2006, National Strategy for Accelerating the Development of Community Utilities, republished). The multiannual development plan for community public utility services aims to ensure the extension, modernization and efficiency of community public utility services and their related technical and municipal infrastructure to European standards, in accordance with the commitments applicable to community public utility services, assumed by Romania by the Treaty of Accession to the European Union, signed by Romania in Luxembourg on April 25, 2005, ratified by Law no. 157/2005. The multiannual development plan for community services of public utilities is correlated with the National Development Plan, which is the document of strategic planning and multi-annual financial programming that aims to guide and stimulate Romania's economic and social development, in order to achieve economic and social cohesion. The national development plan was drawn up at the request of the European Commission as one of the basic requirements for accessing, initially structured pre-accession funds (Phare, Ispa, Sapard) and then structural and cohesion funds.

In this regard, we emphasize the indisputable role of inter-community development associations that provide the unitary legal and institutional framework for implementing the provisions of the National Strategy for Accelerating the Development of Community Utilities and the Multiannual Plan for the Development of Community Utilities. 
From the point of view of the architecture of the system of organization and functioning of public utility services, the important moment is 2016 when following the change of the legal framework, the local public administration authorities are free to decide on the management of public services under their responsibility. the possibility to manage the services directly, on the basis of a management decision, or to entrust their management, respectively all or only part of their own competences and responsibilities regarding the provision of a service, or of one or more activities included in the respective service, based on a management delegation contract (Art. 22 of the Law on Community Public Utilities Services no. $51 / 2006$, republished, with subsequent amendments and completions, as amended by Law no. 225/2016).

"The public utility services are the responsibility of the local public administration authorities or, as the case may be, of the inter-community development associations aiming at the public utility services, according to the mandates granted to them by decisions of the deliberative authorities of the member administrative-territorial units. The local public administration authorities have exclusive competence, under the law, in all matters regarding the establishment, organization, management and operation of public utility services, as well as in the creation, development, modernization, rehabilitation and operation of public or private property of the administrative-territorial units that make up the public utility systems" (Law no. 225/2016 amending and supplementing the Law on community services of public utilities no. 51/2006).

Two or more administrative-territorial units, may cooperate and associate within the competences of their deliberative and executive authorities, may cooperate and associate, in accordance with the law, in order to establish inter-community development associations with the aim of providing jointly of community public utility services and the establishment, modernization, rehabilitation and / or development, as the case may be, of the related public utility systems. Intercommunity development associations aiming at public utility services are cooperation structures with legal personality of private law and public utility status recognized by law, intended to exercise and jointly exercise the powers of local public administration authorities regarding the provision / provision of public services. public utilities, established in their charge (Law no. 215/2001, republished, with subsequent amendments and completions, and of the Framework Law on decentralization no. 195/2006) "The legal relations between the local public administration authorities or, as the case may be, between the inter-community development associations aiming at the public utility services and users, established on the basis of the legal provisions, are legal relations of administrative nature, subject to legal norms of public law. Public utility services are provided / provided through operators or regional operators. The legal relations between the local public administration authorities and the operators, established on the basis of the provisions of the present law, are subject to the legal norms of public or private law, as the case may be."

As mentioned also in previous reviews a conclusion of those presented is that the diversity and complexity in the field of public utility services is all the more accentuated as each type of public utility service (water supply; sewerage and wastewater treatment: collection, sewerage and drainage of rainwater; centralized heat supply; sanitation of localities; public lighting; natural gas supply; local public passenger transport) are different from the perspective of the operating area, so 
there are utilities organized at the level of local administrative unit (communes, cities, municipalities with or without the metropolitan area), county (full or partial coverage) or regional, each being regulated both by a general legal framework and by special laws, which gives it specificity.(Aniko Kuntz, 2019, Indicatori specifici în analiza performanţei financiare a serviciilor de utilităţi publice)

\section{Public utility service in the field of water, sewerage and wastewater treatment, collection, sewerage and drainage of rainwater in Romania}

As a result of the fact that the public water supply and sewerage service has a direct impact on the health of the population, the quality of life and last but not least on their standard of living, at the time of signing the Accession Treaty, Romania has undertaken important commitments to transpose the acquis communautaire in the drinking water and wastewater sector. These represent the transposition of Directive 98/83 on the quality of water intended for human consumption, Directive 91/271 / EC / 19916, as amended and supplemented by Directive 98/15 / EC / 19987 on the treatment of urban waste water. In this sense, Romania is committed to making large investments in a relatively short transition period. At the same time, due to the fact that the entire territory of Romania was declared a sensitive area, all human settlements with over 10,000 inhabitants had the obligation to make investments related to high-performance treatment plants.

According to the Report on the sectoral investigation launched by Order no. 82 from 15.02.2017 "Romania declared its entire territory as a sensitive area, this aspect implying the obligation that all human agglomerations with more than 10,000 inhabitants be provided with treatment plants with advanced degree of treatment. In this sense, the appropriate strategic direction is represented by the promotion of major regional infrastructure investment projects, doubled by the regionalization of utilities as a key element in improving the quality of services and the efficiency of capital and operating costs".

In fact, since the pre-accession period to the European Union, the operators of public utility services in the field of water and sewerage have carried out important programs with various sources of financing (EBRD, ISPA or SAMTID). Through the continuous evolution of the economic and social situation, combined with the alignment to the legislative changes of the period, not least through the emergence of regional operators and inter-community development associations, public utilities in the field of drinking water and sewerage have registered a significant development. primarily by the volume of investments made. Existing operators become regional operators of the public water supply and sewerage service, in order to create the premises for accessing investment projects with European funding related to the Sectoral Operational Program Environment 2007-2013, followed by those in the Large Infrastructure Operational Program 2014-2020. In order to ensure the necessary co-financing for the implementation of the ISPA, SAMTID and SOP Environment programs, external loans have been committed. Most of these operators have accessed external loans, especially state-guaranteed EBRD loans. In these loan agreements, the EBRD imposed a program of measures to improve financial and operational performance, the main conditions of which were: increase tariffs for public utilities, debt service coverage through cash flow; control of customer debts, control of production costs and establishment of the I.I.D Fund (maintenance, replacement, development). As the existence of this 
fund proved its usefulness in daily practice, but also because the process of redirecting European funds to the aspects of economic and social cohesion in the context of Romania's accession to the European Union continued, the need to create a legal framework. This is all the more so as there has been legislation since 2003 that the financing treaties and memoranda between the Romanian Government and the European Commission enter into force on the date of their signing, without the need to go through their ratification procedure (Law no. $590 / 2003$ on treaties). Considering that the rules and procedures of the European Commission, imposed as a way of working to the entities that accessed these nonreimbursable funds, but not assumed by the Romanian Government, led to a series of discrepancies with the financial-accounting rules generally applicable in Romania, the legislator approves 2005 Emergency Ordinance no.198 on the establishment, supply and use of the Maintenance, Replacement and Development Fund for public service infrastructure development projects that benefit from nonreimbursable financial assistance from the European Union. The purpose of the existence of this fund remains essentially identical to the one provided by the loan agreements, respectively to ensure the necessary sources to cover the public debt service, as well as to ensure the continuity in the operation of the public utility services. The emergency ordinance regulates the minimum obligations of the operator or administrative-territorial unit regarding the establishment of the IID Fund, allowing the modification according to the concrete conditions of the projects and the requirements of the financiers, but limits the initiation competence at the Ministry of Public Finance (GEO no.198 / 2005, updated). The supply source of the fund is at least equal to: the royalty related to the concessioned goods, the profit tax paid by the operator to the administrative-territorial unit; cash and cash equivalents, amounts from undistributed net profit, respectively dividends made, VAT paid from the IID Fund and subsequently recovered from the state budget, other own sources of the operator (if applicable). The inclusion of the royalty in this fund actually provides the sources of financing for future investment works in the public utility system, an important desideratum considering the permanent character and the continuous operation regime of the public utility services.

In the case of water and sewerage, according to the service concession contracts, the royalty represents a certain percentage of the value of the invoiced production, ensuring the legislative provision according to which the royalty represents the source of future investments in the field.

We mention that in the field of water and sewerage utilities the IID fund is constituted at the level of operators and not at the level of inter-community development associations, which has the disadvantage that the implementation of the National Strategy on accelerating the development of community public utility services is difficult. development of community public utility services, respectively the National Development Plan Also, each operator has its own development and tariff strategy, limited by their operational risk, so that unitary and nondiscriminatory consumer access is applicable in view of the existing conditions in the areas operating.

Viewed through the investment programs implemented in the field of water, sewerage and wastewater treatment, rainwater collection, we can unequivocally conclude that the IID fund has proven its usefulness. 
4. Empirical study on investments made in the Maintenance Fund, replacement of development in the field of water, sewerage and wastewater treatment, rainwater collection in Romania

In this study we will follow the following aspect:

a) the royalty situation according to the ARA radiography for 2019;

b) The volume of investments made from the IID fund in the period 2012-2019, according to the same source;

c) The volume of investments made by the beneficiary operators and / or not of the MUDP program.

In the database of the Romanian Water Association (ARA) are registered 43 operators in the field of water and sewerage, who have expenses with a royalty between $1 \%$ and $16 \%$ of the value of the invoiced production, the average being cc. $4.5 \%$, according to the study on the radiography of the financial performances of water and wastewater operators in Romania for 2019.

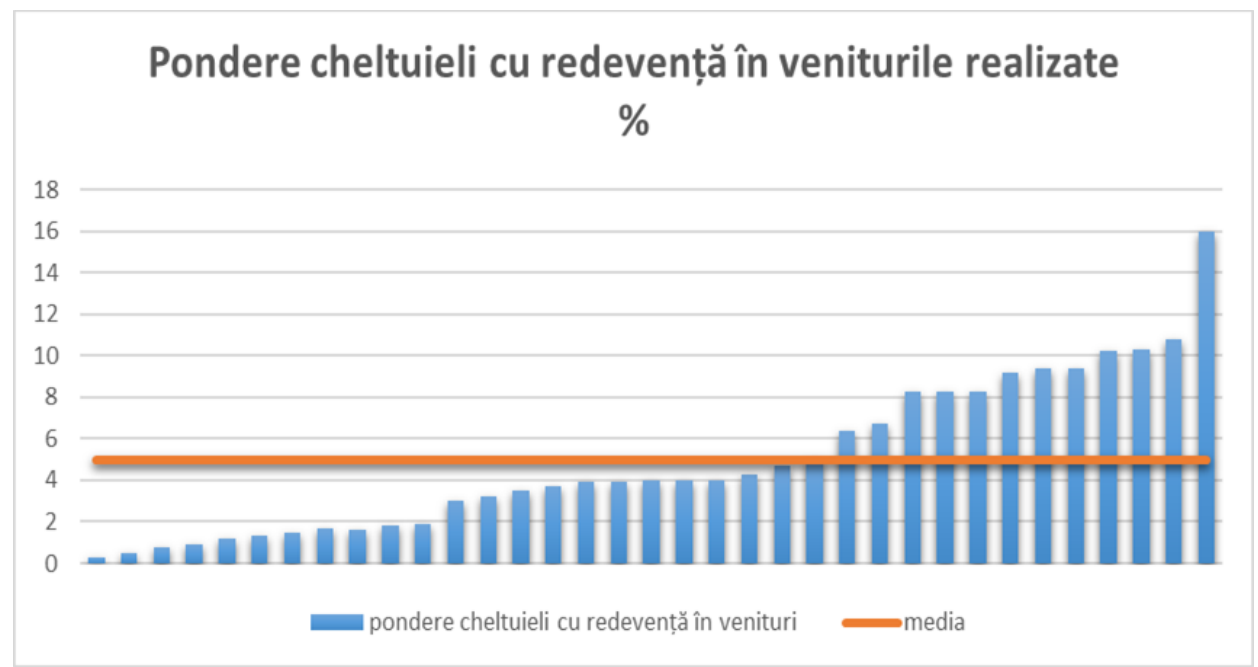

Figure 1: Expenses with royalty from the value of invoiced production Source: Own processing according to ARA data base

The royalty thus conceived, as the main source of supply of the fund, ensured the realization of investments in the amount of 1.405.099.869 lei, in the period 20122019 (according to the information provided by ARA.) Unfortunately, there is no database on the volume of investments made from IID fund for a longer period of years. For comparability, we transformed the value in lei / year into euro / year, using the average euro exchange rate per year, according to the NBR communication. We further used these data to highlight the value of investments made from IID sources by the 43 regional operators in the period 2012-2019.

Table 2: Volume of investments euro / year period 2012-2019

\begin{tabular}{|c|c|c|c|c|c|c|c|c|}
\hline An & $\mathbf{2 0 1 2}$ & $\mathbf{2 0 1 3}$ & $\mathbf{2 0 1 4}$ & $\mathbf{2 0 1 5}$ & $\mathbf{2 0 1 6}$ & $\mathbf{2 0 1 7}$ & $\mathbf{2 0 1 8}$ & $\mathbf{2 0 1 9}$ \\
\hline Total & 31.054 .838 & 33.230 .638 & 36.083 .704 & 35.321 .972 & 42.050 .309 & $\begin{array}{c}36.551 .0 \\
60\end{array}$ & $\begin{array}{c}48.713 .25 \\
9\end{array}$ & 46.361 .365 \\
\hline
\end{tabular}

Source: Own processing according to ARA data base 


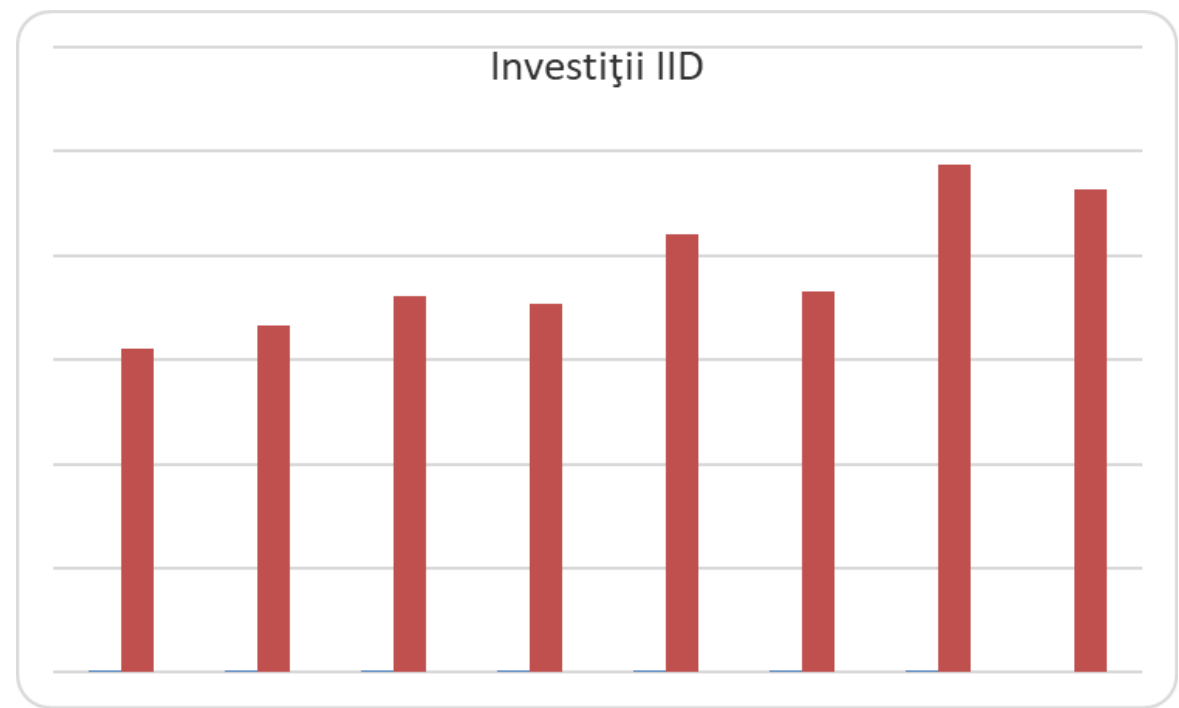

Figure 2: Evolution of investments for the period 2012-2019 Source: Own processing according to ARA data base

We can observe their increasing trend at national level, even if we establish this trend by comparing it at the level of several years and not by comparing it with the previous year. In my personal opinion, due to the lack of unique regulations on the definition / delimitation and classification of major repair and modernization works, it is possible that some operators, in certain periods, will be borne by the sources related to the production activity, in terms of maintenance costs. and repairs. The motivation is a very simple one to avoid the elaboration of the documentation and authorizations necessary for the investment works, but with major implications regarding the correctness and reality of the information provided at national level.

Out of a total of 43 operators, 15 were beneficiaries of the Municipal Utilities Development Program, implemented between 1995 and 2000. The main objectives of the project in the water supply sector were: rehabilitation of distribution networks (including installation of water meters to consumers), restoration of adductions, rehabilitation of wells and springs, construction of tanks, automation of water plants, rehabilitation and modernization of hydrophore stations, introduction of a system for monitoring flows and pressures in the system. It took place in two stages, as follows:

- MUDP I: Iasi, Mures, Timis, Brasov and Dolj;

- MUDP II: Arad, Bacau, Braila, Constanta, Vrancea (Focsani), Bihor, Dambovita (Targoviste), Bistrita, Botosani, Cluj

If we follow the evolution of the investments made from the maintenance, replacement, development fund at these 15 operators, which represent approximately $30 \%$ of the total regional operators in Romania, we will find that they give $43 \%$ of the total investments made at national level, in the analyzed period. 
Table 2: The value of investments made from the investment fund through the M.U.D.P.

\begin{tabular}{|c|c|c|c|}
\hline Year & Total & $\begin{array}{c}\text { M.U.D.P. } \\
\text { Program }\end{array}$ & $\begin{array}{c}\text { Without } \\
\text { M.U.D.P. } \\
\text { Program }\end{array}$ \\
\hline 2012 & 31.054 .838 & 15.496 .338 & 15.558 .500 \\
\hline 2013 & 33.230 .638 & 15.018 .277 & 18.212 .361 \\
\hline 2014 & 36.083 .704 & 14.368 .999 & 21.714 .705 \\
\hline 2015 & 35.321 .972 & 17.357 .136 & 17.964 .836 \\
\hline 2016 & 42.050 .309 & 15.794 .647 & 26.255 .662 \\
\hline 2017 & 36.551 .060 & 16.778 .306 & 19.772 .753 \\
\hline 2018 & 48.713 .259 & 20.606 .169 & 28.107 .090 \\
\hline 2019 & 46.361 .365 & 20.523 .256 & 25.838 .110 \\
\hline General Total & 309.367 .145 & 135.943 .127 & 173.424 .018 \\
\hline
\end{tabular}

Sursa: Own processing according to ARA data base

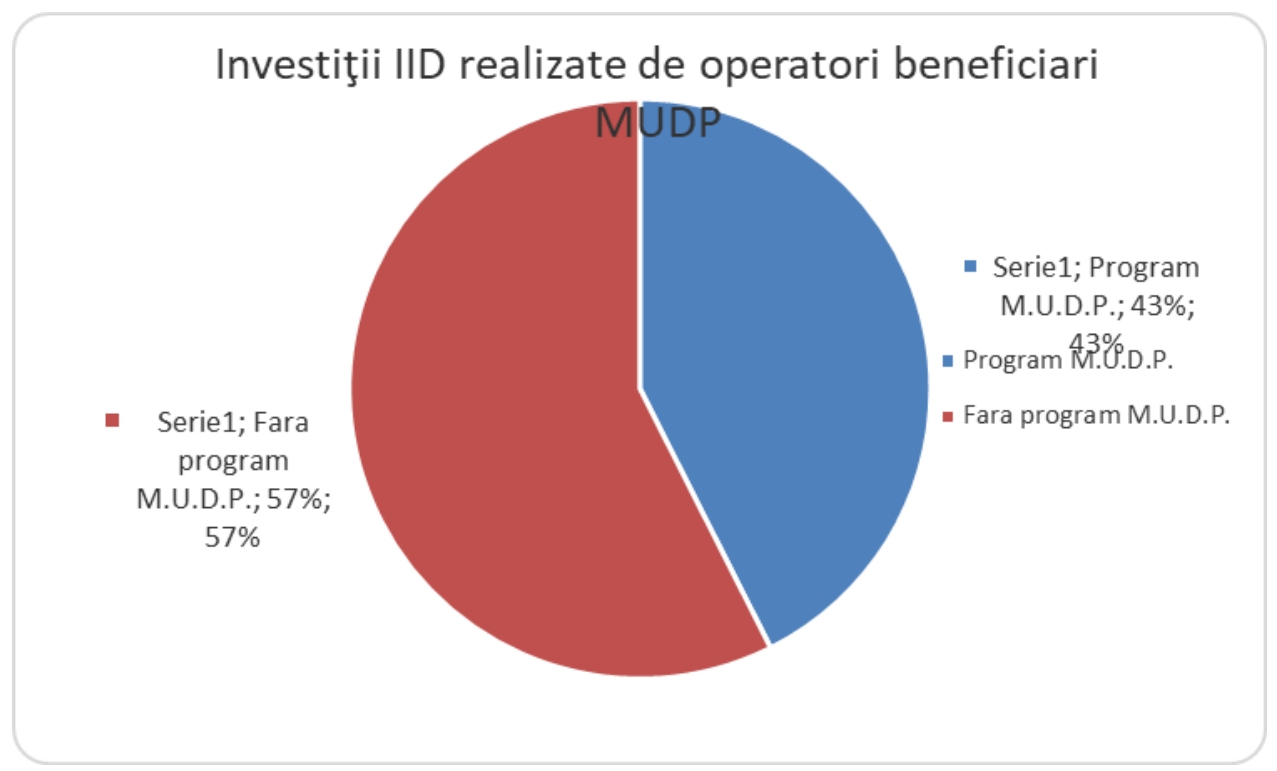

Figura 2: IID investments made by MUDP beneficiaries

Sursa: Own processing according to ARA data base 
Given the volume of investments made, we can unequivocally conclude that the existence of this fund has proved its usefulness, especially since their implementation takes place after the payment of the debt service, which proves a good financial balance, with a cash flow. positive, at the level of the entire field of public water and sewerage services.

From the point of view of the operators, other advantages of setting up the fund are:

- ensuring continuity in the operation of public utility services, by reducing the risk of operation due to the fact that neither the operating expenses nor the cash flow do not include the costs of modernization, replacement, development of the public utility system (these being pursued separately by a separate chapter of the investment plan),

- also the debt service has ensured the distinct financing source, without charging the costs of the operators, costs that are the basis for the calculation of the operating tariffs. Through this financing mechanism, the effort to modernize, replace, develop the public utility system remains with the owner (territorial administrative unit), without distorting the tariffs applied to users by including both royalties and debt service. ;

- creates the premises for continuing and / or accessing investment programs in public utility systems of regional or zonal interest that benefit from nonreimbursable financing from the European Union, by ensuring the co-financing of these programs, facilitating access to these projects;

From the point of view of the owners of the public utility system, the advantages would be the following:

- ensuring the implementation of the National Strategy on sustainable development, protection and capitalization of the public and private domain of the administrative-territorial units, not least the acceleration of the development of community services of public utilities in a unitary and non-discriminatory way

- compliance with the commitments assumed by Romania through the Accession Treaty regarding the quality requirements, protection and conservation of the environment, in accordance with the acquis communautaire,

- ensuring the source of financing of investments from this distinct fund, has the direct effect of eliminating and / or considerably reducing the subsidies for investments from the state or local budget,

- also ensures the correlation of the national legal framework with the requirements of the treaties and financing memoranda of the European Commission, from a financial-accounting and fiscal point of view, having as direct effect transparency and comparability in the activity of evidence and reporting at all levels.

- compliance with the purpose for which the royalty was defined as a source of financing for future investment works in the public utility system, an important goal considering the permanent character and the continuous operation regime of the public utility services

In our personal opinion, in Romania, there is a legislative vacuum precisely in the traceability of financing public utility systems, in the sense that the royalty obtained by exploiting the public and private patrimony of territorial administrative units, corroborated with the permanent character and continuous operation of utility services public, generates the need to "reinvest" the royalty in the system, decision-making and financial mechanism regulated only partially. This deficiency 
is solved in other forms, such as subsidies or tariff increases for public utilities, but solutions that have many shortcomings, both economically and socially.

\section{Conclusions}

The establishment of inter-community development associations ensures the necessary framework for the organization, regulation, financing, operation, monitoring and joint management of public utility services provided within the competence of the administrative-territorial member units, as well as the joint realization of investment projects, public works of zonal or regional interest intended for the establishment, modernization and / or development, as the case may be, of public utility systems. Also, these associations ensure the implementation of the National Strategy on accelerating the development of public utilities, the Multiannual Plan for the development of public utilities, respectively the National Development Plan and last but not least facilitates access to nonreimbursable funds, cross-border, overall provisions with a special impact on public utility services, especially in terms of environmental and quality issues, materialized by firm commitments to make investments in the field. The establishment of the maintenance, replacement, development fund at the level of inter-community development associations ensures the source of financing for the implementation of all the desideratum in the field of public utility services.

Considering the permanent character and the continuous operation regime of the public utility services, there is an indisputable need to continue the implementation of multiannual development projects aimed at developing the infrastructure of public utility services, improving the environment and quality, setting up the maintenance fund, replacement, development being an element of interest and a starting point in the study of performance and in the elaboration of diagnostic analyzes applicable to the entities in the field of public utility services.

\section{References}

1. Anastase,I.,Managementul serviciilor publice de interes local.Echilibrul BowenLindhal-Samuelson într-o nouă perspectivă, Performance and Risks in the Europen Economz, vol3, univ-danubius.ro,2008;

2. Bărbulescu, C., Bâgu, C.,Managementul producţiei, vol. II - Politici manageriale de producţie, Editura Economică, Bucureşti, 2001;

3. Bedrule-Grigoruta,M.,V.,Managementul serviciilor publice, Note de curs,Ed.Tehnopress laşi, 2007;

4. Constantin,D.L., Elemente fundamentale de economie regională, Ed.ASE, Bucureşti, 2004;

5. Demeter, J., Klarik,L. A., Regionalis torekvesek Erdelyben, Europrogress, nr.6,pp.11-14, Budapest,2003;

6. Dinu, C.G., Influenţa Directivei 214/23/UE privind concesiunile asupra dreptului naţional român, Revista Transilvană de Ştiinţe Administrative, 2 (39), pp. 7387,2016;

7. Grigorescu, A., Serviciile publice între nevoia cetăţeanului şi posibilităţile administraţiei, Caietul ştiinţific al I.S.A. „Paul Negulescu” nr.12,2010, online https://mpra.ub.uni-muenchen.de/25132;

8. Icu, M.M., Aspecte esenţiale privind regimul juridic al bunurilor imobile din domeniul privat, Revista on-line Universul Juridic, 10 ian.2020; 
9. Focşăneanu,D., Şuţa, C.,Tatu, C.,Popescu,M., Serviciile publice.Consideraţii asupra legislaţiei şi practicii comunitare în domeniu, în contextul elaborării proiectului Codului Administrativ, Revista Transilvană de Ştiinţe Administrative, 1(28),pp31-39,2011;

10. Klarik, L.A, Rolul regiunilor în construcţia europeană. Studiu de caz asupra regionalismului din România, Revista Transilvană de Ştiinţe Administrative, nr.3, Cluj-Napoca, pp.76-82,2004;

11. Kuntz, A., Indicatori specifici în analiza performanţei financiare a serviciilor de utilităţi publice, 2019;

12. Kuntz Aniko, Driha Cristina A Keynesian Model Applied To The Water And

Sewage Public Utility Operators, paper published in Annals of Faculty of

Economics, University of Oradea, Faculty of Economics, vol. 1(2), pages 179-191, December 2020.

13. Matei ,L., Anghelescu S., Dezvoltarea locală. Concepte şi mecanisme, Ed.Economică, Bucureşti, 2010;

14. Mitlin,D., Walnycki,A., Water utilities'strategies for cost recovery and their consequences for universal access, Journal of development studies, 2020;

Repere legislative:

15. Legea nr.15/1990 privind reorganizarea unităţilor economice de stat ca regii autonome şi societăţi comerciale, publicat M.Of. nr. 98/08.08.1990;

16. Legea nr.151/1998 privind dezvoltarea regională în România, publicat M.Of. nr. 265/16.07.1998, abrogat;

17. Legea nr.213/1998 privind proprietatea publică şi regimul juridic al acesteia, publicat M.Of. nr. 448/24.11.1998;

18. Legea nr.51/2006 serviciilor comunitare de utilităţi publice, republicat M. Of. nr. 121/05.03. 2013;

19. Legea nr. $225 / 2016$ pentru modificarea Legii serviciilor comunitare de utilitati publice nr. 51/2006, publicat in M. Of. nr. 942/23.11.2016;

20. Legea nr.241/2006 serviciului de alimentare cu apă şi canalizare, republicat M. Of. nr. 679/08.09. 2015;

21. Legea-cadru nr. 195/2006 a descentralizării, publicat M.Of. nr. 453/25.05.2006, abrogate

22. Legea nr.286/2006 pentru modificarea şi completarea Legii administraţiei publice locale

23.Raport de activitate 2019 al Autorităţii Naţionale de Reglementare pentru Serviciile Comunitare de Utilități Publice;

24. Raport asupra investigaţiei sectoriale declanşate prin Ordinul nr. 82 din 15.02.2017. 